\title{
Kontrolirana modernizacija za banovanja Ivana Mažuranića*
}

U prilogu se sintetički obrađuje tip modernizacije koju provodi ban Ivan Mažuranić (1873. - 1880.), kao i pitanje odnosa hrvatske intelektualne elite prema vlasti u razdoblju dualizma u Habsburškoj Monarhiji.

Ivan Mažuranić jedan je od najznačajnijih hrvatskih intelektualaca uopće, a njegova je djelatnost bila izrazito široka, obuhvaćajući pravo, filologiju, književnost i politiku. Kao član Hrvatskoga sabora od 1848. godine, potom kasnije kao hrvatski dvorski kancelar, predsjednik Hrvatskoga sabora i naposljetku ban, uvelike je pridonio zamahu modernizacije i nacionalne integracije u Hrvatskoj. Dosljedno se u okviru tadašnje političke prakse borio za široku hrvatsku autonomiju s obilježjima državnosti, a kao ban uspio je provesti liberalne reforme školstva, pravosuđa i unutrašnje uprave. Kao književnik, političar, pravni stručnjak, prevoditelj i autor rječnika, Ivan Mažuranić je, poput Augusta Šenoe, u jednom životu uspio sažeti pregalaštvo dostatno za njih nekoliko.

U fokusu ovoga teksta dva su tematska kruga: modernizacijske reforme te odnos hrvatskih intelektualaca prema vlasti. Dakako, oba kompleksna pitanja bit će kontekstualizirana upravo u Mažuranićevu dobu.

\section{Hrvatski intelektualci $i$ vlast}

Uobičajeno se Mažuranića smatra jednim od rijetkih hrvatskih intelektualaca koji je uspješno i u hrvatskom interesu obnašao neki segment vlasti, područje kojim do 1918. neprijeporno dominira osobnost Ise Kršnjavog, predstojnika Odjela za bogoštovlje i nastavu Zemaljske vlade 1891. - 1896. godine. Kršnjavog se ponekad ističe prototipom hrvatskog intelektualca kao homo politicusa, makijavelističkog oportunista, koji je unatoč nepovoljnom političkom ozračju

\footnotetext{
Ovaj je tekst izrađen u sklopu projekta Hrvatske zaklade za znanost br. 4153 Croatia and Central Europe: Art and Politics in the Late Modern Period (1780-1945), voditelja prof. dr. Dragana Damjanovića.
} 
za banovanja Károlyja Khuen-Héderváryja uspio realizirati važne projekte za hrvatsku kulturu i prosvjetu. ${ }^{1}$ Ne želeći podrobno ulaziti u raspravu o bez sumnje intrigantnoj i složenoj djelatnosti Kršnjavog, postavila bih pitanje što je uopće u Hrvatskoj značilo biti intelektualac na vlasti u razdoblju dualizma i kako u tom aspektu možemo sagledati djelovanje Ivana Mažuranića?

Budući da su za navedeno pitanje, osim društvenog konteksta, izuzetno važne i karakterne osobine, osvrnula bih se ukratko na Mažuranićevo značenje, započinjući jednom karakterističnom epizodom iz njegova djetinjstva. Kao dječak u rodnom Novom, Ivan bi u kupovinu morao sa sobom povesti mlađeg brata Matiju da s trgovcem komunicira, dočim je Ivan, kao stariji, baratao novcem! ${ }^{2}$ Škrtost na riječima, trezvenost, odmjerenost i jezgrovitost pratit će Mažuranića cijeli njegov život. Za razliku od svojih banskih prethodnika koji su u Hrvatski sabor dolazili u svečanom ruhu - banskom ornatu (raskošnijoj verziji magnatske gale), Mažuranić je najčešće dolazio u građanskom odijelu. U Saboru se uvijek držao suzdržano, ne reagirajući neprimjereno čak ni na najžešće napade. Srpski političar Jovan Subotić ovako opisuje Mažuranićevo držanje u Saboru još u vrijeme kad je bio hrvatski dvorski kancelar: „Nije se maknuo na svom mestu, nije se namrštio, nije pokazao znakove, da ga nešto ljuti ili jedi; nije glavom drmno ni okom nadesno ili nalevo pogledao, nije usta otvorio, nije glasa od sebe dao. Čovek živ, ali od pravog kamena. “3 Mažuranić je, dakle, stoički i suzdržano podnosio i neugodne političke napade i okršaje, nastojeći u svakoj situaciji ostati pribran i trezven te izbjegavati uzbuđenje i emocije.

Mažuranić, poznat po sentencioznosti i sažetosti izričaja, najbolje je sam opisao svoje političko i osobno značenje u govoru koji je održao u Saboru prilikom nastupa na bansku dužnost 30. rujna 1873. Novi je ban tada rekao: „Ja ne poznam nikakove mržnje. Na svijetu nećete naći čovjeka, koji bi mi kazati mogao: ovo je moj neprijatelj, ovaj me mrzi. Nije to zasluga moja, takova mi je narav. Buduć ne poznam privatne, još manje poznam političku mržnju. Ja štujem svako mnijenje koje se vrti na temelju danas postojećega zakona, a ono mnijenje, koje ide preko zakona, i ono zaslužuje katkada da se uvaži, ukoliko ide za reformu zakona. Ja neću nigdje učiniti koraka, koji bi pokazao strast, ali pokazati ću svagdje onu revnost, koja za tim ide, da se službe vrše onako, kako donosi dužnost, da se strogo vrši zakon, da se dobrom upravom povjerenje naroda prama poglavarstvu pobuđuje, da se materijalno dobro naroda promiče, da se moralni razvitak naroda podigne

\footnotetext{
Tako I. Krtalić piše kako se u Kršnjavome realizira ,unikat hrvatskog Fausta“. KRTALIĆ 1986: VI.

2 BARAC 1945: 20.

3 Isto: 55.
} 
u svakom obziru, da se narod podupre u napretku, kako bi mogao stajati dostojan i vrijedan u kolu ostalih naroda monarkije.“4

Gotovo je paradoksalno da se tako suzdržanog i odmjerenog političara žestoko napadalo, na razne načine i iz raznih krugova, kako u taboru političkih protivnika, tako i u onom istomišljenika. Ante Starčević smatrao ga je lutkom Beča, pukim „beamterom“ koji skače za korom kruha i tvrdio je da Mažuranić mjeri vrijednost ljudi prema broju beamterskih zvjezdica, opsegu svijetla ovratnika i po ,dijetenklasah". ${ }^{5}$ U bečkom su središtu Mažuranića 1851. okarakterizirali kao fanatičnog ,ultrailirca“. ${ }^{\circ}$ August Šenoa je, uz niz pohvala, Mažuraniću predbacivao birokratizam, tromost i popustljivost prema Austriji početkom 1860-ih, smatrajući ga zatvorenim čovjekom kojeg svi drže oholim. ${ }^{7}$ Franjo Rački je, pak, 1874., dakle u godini kada se donosi niz važnih reformnih zakona, među inima i onaj o pučkom školstvu i preparandijama, zapisao kako Mažuranić ima prekrasnu poziciju, ali prema njoj nije djelatan i poduzetan, a Strossmayer je smatrao da Mažuranić popušta Mađarima zbog mlitavosti i slabosti. ${ }^{8}$ Čak su i Mažuranićevi prijatelji iznosili ocjene o njegovoj tromosti, rezignaciji ili nevoljkosti, pa ga je, primjerice, Imbro Tkalac odmilja zvao Ivan-paša. Zanimljivo je kako se usporedno s kritikom Mažuranićeve politike javljalo i osporavanje njegova književnog opusa. Iz pera Ante Kovačića potekla je parodija Smrt babe Čengićkinje, a javile su se i sumnje i u samo autorstvo epa. Mažuranićev politički uspon ili pad pratila su poneka osporavanja ili glorificiranja njegova književnog opusa, a na recepciju pojedinaca nerijetko je utjecala i njihova politička orijentacija. ${ }^{9}$

No, Mažuranićeva moralnost i osobno poštenje bili su neupitni u svim krugovima. Svoje brojne talente stavio je u službu domovine, dovodeći se nerijetko u nepovoljnu materijalnu situaciju. Iako je kao čelnik Hrvatske dvorske kancelarije bio nazočan sjednicama Ministarskog vijeća te je pripadao samom hrvatskom političkom vrhu, morao je sebe i svoju obitelj primorati na štednju. Supruzi Aleksandri, rođ. Demeter, slao je većinu svoje plaće i stalno je poticao da bude

4 MAŽURANIĆ 1979: 219-220.

5 Tj. razreda koji označavaju rang činovnika i visinu njihove plaće. BARAC 1945: 24, 27.

6 Franjo Josip I. na sjednici Ministarskog vijeća 2. siječnja 1851. nazvao ga je prvoborcem ultrailirske stranke. ŽIVANČEVIĆ 1988: 100.

7 Posrijedi je razdoblje kada Mažuranić kao hrvatski dvorski kancelar surađuje s centralističkim režimom austrijskog ministra predsjednika Antona Schmerlinga. ŠENOA 1951: 575-588. BARAC 1945: 47 navodi da je Šenoa zapisao kako su se Mažuraniću od beamterstva osušila čuvstva, no taj navod nisam našla u Šenoinu tekstu.

8 BARAC 1945: 22, 42.

9 Tek je malobrojni krug, mahom Mažuranićevih prijatelja, spoznao umjetničku vrijednost epa prije njegova političkog uspona, dočim se Starčević o njemu nepovoljno izražavao. Dok je Mažuranić bio ban, Armin Pavić je njegovu dopunu Osmana čak proglasio boljom od samog Gundulićeva teksta. PAVIĆ 1875: 104-150; BARAC 1945: 28-29. 
skromna, opisujući joj i mnogobrojne teškoće s kojima se susreće. Primjerice, u pismu od 13. siječnja 1861. opominje ju da racionalno troši novac, naglašavajući kako su „protivštine i težkoće“ znatne te „ako jos dodje kojekakovo klevetanje odozdo, ja ću učinit kratak proces i vratit se doma." Istaknuo je i da se u domovini misli kako on ima ,za podielivanje punu vreću službah i to čim mastnijih; a meni ovdie nedadu postojanoga činovnika“ “. ${ }^{10} \mathrm{U}$ pismu supruzi iz Beča 7. veljače 1861. piše kako mu mjesečno ostaje 408 forinti, od kojih mora izdržavati obitelj u Zagrebu i sebe u Beču, pa će se još morati zadužiti! S gorčinom je dometnuo: „To ti je dakle ta velika služba, za koju mi bog zna tko zavidi!“, napomenuvši i kako je već bio pripravan dati ostavku, od koje je, doduše, na nagovor prijatelja odustao, ali je u svakom trenutku spreman otići s položaja. ${ }^{11}$

Hotimice sam opsežnije citirala mahom samog Mažuranića kako bih postavila pitanje zašto je trezven, pošten, tolerantan i svestran intelektualac poput njega izazivao takve reakcije? Zašto je stalno spreman dati ostavku na položaj hrvatskog dvorskog kancelara? Zašto je naposljetku sam otišao s banske stolice? Jednoznačan odgovor nije lako dati, no mišljenja sam da nedovoljna razvijenost Hrvatske, kao i stalna ovisnost o stranim centrima moći te nepostojanje široke autonomije uvjetuju da se ne artikulira moderna politička kultura sve do kraja 19. stoljeća. Političkom arenom dominira društveno-humanistička inteligencija, koja ima presudan utjecaj i na oblikovanje nacionalnog pokreta, dočim se prirodoznanstvena, medicinska i tehnička inteligencija, kao i moderna umjetnička scena oblikuju sa zakašnjenjem. Iz navedenih razloga u nacionalnom diskursu javlja se glorificiranje otpora, makar i verbalnog, a ne konkretnih postignuća ako su plod kompromisa sa stranim centrima moći, Bečom ili Peštom. Stoga je svatko tko je u Hrvatskoj obnašao neku dužnost percipiran kao vlastodržac kojeg valja izložiti kritici, pri čemu se ponekad nije vodilo računa o tome koliki je doista opseg te vlasti. Oni koji su se uspeli na ljestvici izazivali su zavist onih koji u tome nisu uspjeli, tadašnjih - kako se govorilo - „kruhoboraca“, a nemali dio intelektualaca nije imao ni interesa ni saznanja o tome kako funkcionira mehanizam modernih tijela izvršne vlasti u svakodnevici. Otuda ruganje činovnicima zatrpanim papirima, ljudima kojima je silno administriranje potisnulo ljudskost i emocije te ih pretvorilo u bezlične i bezosjećajne kreature, puka piskarala. Percepcija je Vlade često u biti polazila od pozicije njene pretpostavljene vlasti, a ne realnog položaja u političkim i državnopravnim konstelacijama. Nerijetko se od hrvatske Vlade očekivalo zalaganje za velike, makar i neostvarive ciljeve, a ne svakodnevno povlačenje sitnih poteza. Nemali je dio hrvatske javnosti tako preferirao velike geste i junačke riječi i djela, čak i ako od njih nije bilo neke neposredne koristi.

10 MAŽURANIĆ 1979: 132.

11 Isto: 139. 
Poznata afera s „vritnjakom“ banu Károlyju Khuen-Héderváryju u Hrvatskom saboru 1885. godine pokazuje tipično hrvatsko nazdravičarstvo i nesklonost realnoj politici. Pravaši se uzdaju u tradicionalni kodeks časti kako bi riješili politički problem, naivno se uzdaju u to da će obeščašćeni Khuen demisionirati, a nakon samog događaja rašireno je ispijanje zdravica iz staklenih čizmica jer je ban dobio udarac čizmom. Pravaši Josip Gržanić i napose David Starčević prerasli su u prave pučke tribune. ${ }^{12}$ Trijumfalizam je bio kratkoga daha; Starčevićeva karijera, kao i cijeli život su zapravo bili uništeni, a konkretna politička posljedica svega bilo je pooštravanje saborskog poslovnika koje je Khuenu omogućilo da bolje kontrolira rad toga važnog zakonodavnog tijela i prikaže oporbu (tj. pravaše) kao nezrele i neodgovorne političare sklone ekscesima i stoga nepodobnima za vlast. Pravaši su tako pokazali ne samo krivu procjenu političke konstelacije, nego i nepoznavanje protivnika. Naime, Khuen se pravio kao da udarac u stražnjicu uopće nije ni dobio, a ostavka zbog povrijeđene časti nije mu uopće padala na pamet!

Tipična je za Mažuranića njegova intervencija u korist Starčevića i Gržanića, iako su pravaši bili njegovi politički protivnici, a Ante Starčević se u više navrata vrlo nepovoljno o njemu izražavao. Mažuranić je nakon izrečene presude pisao ministru pravosuđa Aloisu Pražaku, upozoravajući da je posrijedi politički motivirana presuda (,Dass es sich hierbei in erster Linie um politische oder politisch gefärbte, daher der unverfälschten Justiz vollkommen fremde Zwecke handelt"). ${ }^{13}$ Premda je zbog afere došlo i do interpelacije u Carevinskom vijeću, austrijski ministar predsjednik Eduard Taaffe neformalno je upozorio Mažuranića da su posrijedi državni interesi. ${ }^{14}$ Značilo je to da se zbog te afere ne žele pogoršavati odnosi s Mađarima jer bi to predstavljalo ugrožavanje dualističkog sustava. Politička jednadžba bila je stoga jednostavna; Khuen je produžena ruka mađarske Vlade u Banskoj Hrvatskoj, a bečko središte ne kani zbog Hrvatske dovoditi u pitanje svoje odnose s Budimpeštom jer bi to istodobno značilo i krizu državnopravnog ustroja cijele Monarhije.

Valja podsjetiti da od sklapanja Austro-ugarske nagodbe službena komunikacija između Zagreba i Beča ide isključivo preko Pešte. Hrvatsko-ugarskom nagodbom uvedena je dužnost hrvatsko-slavonsko-dalmatinskog ministra u ugarskoj Vladi,

12 U svojim uspomenama pravaš Ivan Peršić opisuje tu atmosferu trijumfalizma i nazdravičarstva, ali i pogubne posljedice za D. Starčevića. „U utorak 18. svibnja 1886. izašli su David i Geržanić iz zatvora dočekani tisućama naroda, i odpraćeni k janjetu (gostionica, op. I. I.). Tu su bile čestitke, tu banket, na večer komersi. Sutradan je kakovih trideset kočija odpratilo Davida kući u Jasku. U jednim kolima bio sam i ja s otcem, David se vozio u cvijećem nakićenom četveropregu. To je mislim, bila zadnja njegova slava u vedrini, u cvijeću u triumfu, ničim nepomućivana. On je prošao sve faze od Hosana do Kalvarije (...).“ PERŠIĆ 2002: 54-55.

13 Pismo od 11. ožujka 1886. u: MAŽURANIĆ 1979: 199-201.

14 ŽIVANČEVIĆ 1988: 130. 
čiji je zadatak bio upravo posredovati između bana i Zemaljske vlade s Peštom i vladarom. Također valja podsjetiti na način postavljanja bana, kojeg imenuje vladar, ali na prijedlog i uz supotpis ugarskog ministra predsjednika. Naposljetku treba ukazati na institut predsankcije, prema kojem nijedan zakonski prijedlog nije mogao doći na dnevni red Hrvatskoga sabora a da to prethodno nije odobrio vladar. Budući da je u hrvatsko-mađarskim odnosima Franjo Josip I. morao prihvaćati sugestije mađarske Vlade kako ne bi ugrozio dualizam kao takav, predsankcija je de facto otvarala prostor ugarskoj Vladi da utječe na zakonodavstvo i u hrvatskim autonomnim poslovima. S obzirom na sve navedene mehanizme čvrste kontrole Pešte nad službenim Zagrebom, velika je sreća bila to što je Mažuranićeva Vlada bila vrlo učinkovita, pa je većina reformnih zakonskih prijedloga bila odobrena u Hrvatskom saboru do 1875. godine. Tada je na ugarskoj političkoj sceni došlo do važne promjene, a novi ugarski ministar predsjednik Kálmán Tisza postavio je prema Hrvatskoj oštriji smjer od svojih prethodnika, političkih sljedbenika Ferenca Deáka. Nakon 1875. godine ban Mažuranić susreće se s brojnim teškoćama. Ugarska se Vlada sve oštrije miješa u hrvatsku autonomiju, događaju se povrede Hrvatsko-ugarske nagodbe, odugovlače se pregovori o obnovi financijskih odredbi Nagodbe. Također se oteže pripojenje Vojne krajine Banskoj Hrvatskoj, a bitna pitanja poput trase krajiške željeznice rješavaju se izvan Hrvatske, što dovodi od ogorčenja i skupštinskog pokreta u Hrvatskoj. U hrvatskoj se javnosti sve češće govori kako je u Hrvatskoj moguće tek ,ugrificirano hrvatstvo“ $i$ iako je poznato da je i sam ban nezadovoljan situacijom, ogorčenje javnosti sve se više fokusira na njega. ${ }^{15}$

Što, dakle, u tako nepovoljnim okolnostima poslijenagodbene Hrvatske uopće znači biti na vlasti, poglavito biti intelektualac na vlasti? Zbog faktičnog nepostojanja široke hrvatske autonomije s obilježjima državnosti i uglavnom nepovoljnih političkih prilika ta je vlast mogla imati samo intrinzično značenje u implementaciji. I taj je unutrašnji domet vlasti stalno bio pod paskom stranih centara moći i izvrgnut intervencijama; pojednostavnjeno rečeno, mogućnosti implementacije vlasti u Hrvatskoj nisu odgovarale njenoj recepciji.

\section{Kontrolirana modernizacija}

Ukratko ću prikazati hrvatsku modernizacijsku vertikalu kako bi bila jasnija Mažuranićeva uloga u tom procesu. Modernizacija nedvojbeno započinje 1848./1849., kada hrvatska elita, lišena kontrole Beča i Pešte, ima priliku formulirati liberalne reforme. No, zbog objektivnih okolnosti - sloma „proljeća naroda“

15 O Mažuranićevu banovanju općenito vidi GROSS I SZABO 1992. Upućujem i na izvrstan i malo poznat doktorski rad: KROKAR 1980. O reformama vidi ČEPULO 1998; Isti 2000: 889920. O školskoj reformi vidi ŽUPAN 2002. 
u cijeloj Habsburškoj Monarhiji i donošenja Oktroiranog ustava 1849. godine, reformni zahvat ostao je tada dobrim dijelom na papiru. Tek tijekom neoapsolutizma počinju konkretne modernizacijske reforme odozgora, provođene iz bečkog središta često i bez obzira na specifične prilike u pojedinim zemljama Habsburške Monarhije. ${ }^{16}$ Nakon obnove ustavnosti dominira državno-pravna problematika i pitanje preustroja Monarhije u federalističkom, centralističkom ili dualističkom smjeru; 1860-e su stoga protekle u borbi za formu - šroku hrvatsku autonomiju s obilježjima državnosti, a ne za sadržaj - odnosno, provođenje konkretnih reformi. Ta se situacija mijenja tek početkom 1870-ih, kada su iz različitih razloga Narodno-liberalna stranka i ugarska Vlada usmjerene na stanoviti politički kompromis. Prva napušta svoju načelnu politiku nepriznavanja Hrvatsko-ugarske nagodbe stoga što je nakon ostavke austrijskog ministra predsjednika Karla Hohenwarta, sklonog svojevrsnoj nagodbi s Česima, postalo izvjesno da je dualizam dugotrajnije rješenje. Želi li imati ikakva utjecaja na unutrašnju situaciju u Hrvatskoj i tijek modernizacije, Narodno-liberalna stranka mora prihvatiti realnu politiku. Ugarska Vlada, koju poslije odlaska Gyule Andrássyja na mjesto austrougarskog ministra vanjskih poslova vodi Melchior Lónyay, svjesna je nakon izbornog uspjeha Narodno-liberalne stranke da poslijenagodbeni režim u Hrvatskoj nije uspio pacificirati političku scenu i stoga je sklona kompromisu s tom strankom. Jedna je od bitnih posljedica dogovora i dolazak Mažuranića na bansku stolicu, a godine 1873. - 1875. zapravo su zlatno razdoblje reformi, premda su one skučena dosega jer su uvjetovane opsegom hrvatske subdualističke autonomije. Za banovanja K. Khuen-Héderváryja one posustaju, ponegdje su povučeni čak i retrogradni potezi, primjerice, u izbornoj legislativi, nametanju prosvjetnog celibata učiteljicama, protezanju nadležnosti velikih župana na gradove itd. Tek je na samom kraju 19. stoljeća, zahvaljujući promijenjenoj političkoj situaciji, kako u cijeloj Monarhiji, tako i u Banskoj Hrvatskoj (izražena kriza dualizma, ujedinjenje hrvatske oporbe, stasanje mlade generacije, stanovita ekonomska konjunktura...) ponovno došlo do poleta. Početkom 20. stoljeća razvidna je djelatnost nove generacije javnih djelatnika u politici, kulturi i drugim područjima, među kojima su izražene ne više samo liberalne, nego i demokratske ideje te naglašena sklonost političkoj praksi, a ne isključivo retorici. Stoga u tom razdoblju dolazi do političke diferencijacije osnivanjem novih političkih stranaka poput Hrvatske pučke seljačke stranke ili, pak, formuliranjem novih politika poput politike ,novoga kursa“, na temelju koje je izrasla Hrvatsko-srpska koalicija, koja će, doduše, ostati vjerna izrazito kritičkoj retorici prema službenoj Budimpešti i Beču, ali će doskora zapravo postati režimskom političkom snagom. ${ }^{17}$ Unatoč tome, Koalicija je imala zasluge u moderniza-

16 Vidi GROSS 1985.

17 GROSS 1960; SCHÖDL 1990; MILLER 1997; CORNWALL 2010: 239-270. 
cijskom procesu jer je bila politički eksponent domaćeg kapitala zainteresiranog za ekonomsku modernizaciju i jer je potezima poput proširivanja prava glasa ipak označila male pomake u političkoj modernizaciji. No, možda je najvažnija njena tekovina bila politička retorika od koje nije mogla odustati ni onda kada je napravila kopernikanski obrat prema režimu. Ta je retorika bila izrazito kritična prema centrima moći, jugoslavenski orijentirana, ali bez tlapnji o jednoj jugoslavenskoj državi i prije svega usmjerena traženju saveznika protiv jake Njemačke i njenog saveznika Austrije, među dojučerašnjim političkim protivnicima - mađarskoj oporbi te Italiji. Ta je politika napose osupnula bečko središte, pokazavši da se na tradicionalnu hrvatsku bezuvjetnu lojalnost ne može tako jednostavno računati te da je politička elita u Hrvatskoj sposobna tražiti nove samostalne putove.

Hrvatska modernizacijska vertikala obilježena je tako vrlo neravnomjernim tempom i opsegom modernizacije, mahom uvjetovanim općim političkim i državnopravnim okolnostima. Kao dinamičnije faze pokazuju se 1850 -e godine, potom Mažuranićeve reforme 1873. - 1875. te razdoblje kraja 19. i početka 20. stoljeća. Najuspješnija je bila modernizacija na polju kulture i prosvjete, dočim je ona na ekonomskom i političkom planu bitno slabija. Uostalom, takva je heterogena slika karakteristična za modernizaciju u cijeloj Habsburškoj Monarhiji, u kojoj je početkom 20. stoljeća u austrijskoj polovini bilo provedeno opće pravo glasa, ali u ugarskoj nije, zbog straha tamošnje političke elite od političkog utjecaja koji bi tako stekli nemađarski narodi. ${ }^{18}$

Modernizacija se u Hrvatskoj kontrolirala i intrinzično i ekstrinzično, izvana i iznutra. Konkretni modernizacijski potezi započeli su od neoapsolutizma reformama odozgora. Međutim, čak i u kratkotrajnom razdoblju Mažuranićeva banovanja, kada hrvatska Vlada ima priliku oblikovati reforme u opsegu hrvatskih autonomnih poslova i opet je posrijedi modernizacija odozgora, ali ovoga puta ne $u$ formulaciji bečkog, nego zagrebačkog središta. Mažuranićeva ekipa čvrsto profilira reforme, oslanjajući se uglavnom na austrijske i njemačke zakonske predloške, koji su, dakako, dijelom i sami rađeni na temelju zapadnoeuropskih rješenja, francuskih, belgijskih i drugih. Razvidno je očito hotimično izbjegavanje ugarskih modela, čak i ondje gdje bi to bilo logično, primjerice, u pogledu zavičajnosti. Hrvatsko poimanje i značenje te primjena zavičajnosti posve su drukčiji od austrijskih, usmjerenih na reguliranje prava i obaveza lokalne zajednice i njezina pojedinačnog člana, s bitnom materijalnom komponentom. U Hrvatskoj je zavičajnost osnova za ostvarivanje stanovitih političkih prava koja su dio hrvatske autonomije. ${ }^{19}$

S jedne strane, ta ponekad i nekritička upućenost na austrijske i njemačke modele (iako valja istaknuti da je Mažuranićeva Vlada u pravilu vrlo dobro prilagođavala

18 O razlikama između austrijskog i ugarskog dijela Monarhije vidi COHEN 2007: 241-278.

19

ČEPULO 2000: 904-905. 
navedene zakone hrvatskim prilikama, radeći supstancijalne modifikacije, ponekad čak i poboljšanja u odnosu na predložak ${ }^{20}$ ) razumljiva je iz političkih razloga. Mažuranić je ipak manje-više čovjek Beča, a ne Pešte, a s druge strane, Vlada i nije imala preveliki izbor; pitanje je bi li, da se izravno preuzeo, primjerice, neki francuski zakon, on dobio sankciju? Međutim, sklona sam u takvom izboru modela i predložaka vidjeti i tendenciju Mažuranićeve Vlade da se i u tom pogledu distancira od ugarskog utjecaja; na takav Mažuranićev stav imala je utjecaja konkretna politička konstelacija, ali i činjenica da pripada generaciji koja je u školi morala učiti mađarski te da ga je u političko-nacionalnom pogledu uvelike oblikovalo iskustvo 1848. - 1849.

$\mathrm{Na}$ ovom bih mjestu ukratko usporedila razvoj procesa modernizacije i nacionalne integracije u Banskoj Hrvatskoj i Ugarskoj. U potonjoj zemlji oba procesa počinju nešto ranije, pa je nacionalni pokret iniciran već u zadnjem desetljeću 18. stoljeća, a prodor liberalnih reformi zamjetan je 1830-ih godina. U Banskoj Hrvatskoj nacionalni pokret stasa tek 1830 -ih, a pravi zamah liberalnih ideja zamjetan je neposredno uoči 1848. Osim tog vremenskog odmaka, postoje i druge značajne razlike. U Ugarskoj Mađari nisu većinski narod, a među ostalim nacionalnostima nijedna nije dominantna; štoviše, one pripadaju i različitim narodnim skupinama (slavenskoj, romanskoj, germanskoj, a sami Mađari ugrofinskoj). U Banskoj Hrvatskoj Hrvati su većinski narod, ali među ostalim nacionalnostima prevladavaju Srbi, što je slučaj i u ostalim hrvatskim zemljama osim Istre, a etnokonfesionalizam je važno distinktivno obilježje te će pospješiti identificiranje hrvatstva i katoličanstva te srpstva i pravoslavlja. Zbog značajne zastupljenosti Srba hrvatski će se nacionalni pokret prema njima morati jasno odrediti. I sami nositelji pokreta u različitim su njegovim fazama zastupali različite stavove, dočim su ilirci poticali suradnju, nositelji modernih nacionalnih ideologija - jugoslavenstva i izvornog pravaštva - $u$ tom su se pogledu podijelili, pa su pobornici jugoslavenstva isticali suradnju, a pravaši negirali i samo postojanje Srba (i Slovenaca) kao naroda. Pritom su se obje ideologije temeljile na hrvatskom državnom pravu. Naime, i za pristaše jugoslavenstva hrvatsko je državno pravo ključno, pa nije slučajno da je Franjo Rački, kao prvi nedvojbeno moderni hrvatski historiograf, upravo tražio dokumente kojima bi se osnažila hrvatska državnost. ${ }^{21}$ Nadalje, i socijalna struktura nositelja nacionalnog pokreta i modernizacije razlikuje se s ugarske i hrvatske strane. U Ugarskoj je zamjetan plemićki liberalizam ${ }^{22}$, pa je srednje i sitno

$\overline{20}$ Primjerice, iako je hrvatski zakon o pučkim školama i preparandijama bio bitno umjereniji u odnosu na liberalni austrijski zakon iz 1869., koji je poslužio kao model, postulirao je tjelovježbu kao obvezan predmet i za djevojčice, a ne samo za dječake kao u austrijskom zakonu. IVELJIĆ 2011: 125-138; Ista 2009: 25-45

21 GROSS 2004; Ista 2000.

22 Plemićki liberalizam podrazumijeva da socijalno ili regionalno odredljiv dio plemstva zastupa liberalne ideje. U Banskoj Hrvatskoj postoji niz plemića sklonih liberalizmu, ali oni nisu regionalno i socijalno odredljivi. O plemićkom liberalizmu vidi DIPPER 1988: 175. 
plemstvo nositelj obaju pokreta, a u Banskoj je Hrvatskoj ta socijalna struktura heterogena, stoga je, osim građanske elite, važnu ulogu imao i dio plemstva, svećenstva, pa i časnika. Doda li se svemu tome i rascjepkanost hrvatskih zemalja, koje od dualizma definitivno pripadaju različitim polovinama Habsburške Monarhije, jasno je zašto unatoč zamahu liberalnih ideja i s hrvatske i s ugarske strane postoje znatne razlike u oblikovanju modernizacije i nacionalne integracije. Mađari će krenuti putem liberalnih reformi, ali neliberalnog odnosa prema nemađarskim narodima, namećući ideju moderne homogene mađarske države od Karpata do Jadrana, ${ }^{23}$ dočim će s hrvatske strane, unatoč razlikama među političkom elitom, uz historijsko pravo važnu ulogu imati i prirodno pravo, a znatan dio nacionalnog pokreta oslanjat će se na suradnju ne samo sa Srbima, nego i s Južnim Slavenima uopće. Stoga će hrvatsko-mađarski sukobi za dualizma biti neizbježni, pa su gotovo o svemu postojale različite verzije. Dovoljno je podsjetiti na činjenicu da hrvatski i mađarski tekst Hrvatskougarske nagodbe, koja je za Bansku Hrvatsku temeljni zakon, u nekim bitnim elementima nisu značenjski istovjetni, ${ }^{24}$ a navedene razlike nisu slučajne, nego proizlaze iz drukčijeg tumačenja hrvatskog državnopravnog položaja u Ugarskoj: je li posrijedi tek skučena pokrajinska autonomija ili široka autonomija s obilježjima državnosti. ${ }^{25}$

Dakle, za Mažuranićeva se banovanja modernizacija kontrolirala izvana; ona je sputana opsegom hrvatske subdualističke autonomije i pod stalnom je paskom ugarske Vlade koja se miješa i u unutrašnje poslove Hrvatske. No, modernizacija se za Mažuranića kontrolirala i iznutra; ona je posljedica čvrstog programa koji se provodi iz zagrebačkog središta. Mažuranićev reformni program temeljio se na guvermentalnom liberalizmu ${ }^{26}$, u centru kojeg nije individualna sloboda, nego korjenite reforme koje će zahvatiti cijelo društvo. Zato nema zakona o nekim temeljnim građanskim pravima, a zakon o pravu okupljanja više ograničava nego što dopušta okupljanje. U vrijeme zasjedanja Sabora okupljanja unutar radijusa od pet austrijskih milja uopće nisu dopuštena! ${ }^{27}$

23 Zakonski članak XLIV Ugarskog sabora 1868. navodi kako svi ugarski građani tvore naciju u političkom smislu riječi, dakle jednu i nedjeljivu ugarsku naciju. Prava su pridržana pojedincima, a ne kolektivitetima, no politički nasljednici L. Eötvosa i F. Deáka i taj će zakon zaobilaziti, pa će se mađarizacija provoditi svim sredstvima, uključujući i ona koja krše navedeni zakon. KONTLER 2007: 287-288.

24 Primjerice, u hrvatskom se tekstu dosljedno piše o kraljevinama Dalmaciji, Hrvatskoj i Slavoniji, dok u mađarskom stoji izraz koji znači pokrajina, zemlja, a poredak je uvijek Hrvatska, Slavonija i Dalmacija. O tekstu Nagodbe s komentarima vidi Zakoni o ugarsko-hrvatskoj nagodbi 1907. GROSS I SZABO 1992: 232-238.

26 KASCHUBA 1988: 83-108; BRANDT 1988: 136-160; FOUCAULT 1990: 93-101. Foucault termin liberalizam shvaća kao praksu racionalizacije upravne vlasti.

27 „Zakon o pravu sakupljati se“, Sbornik zakona za 1874: 25-28. ČEPULO 1999: 397-427. 
Naposljetku valja napomenuti kako je ozakonjena građanska emancipacija Židova, ali ne i protestanata. ${ }^{28}$

Takav centralizirani i na reforme javne uprave usredotočeni tip liberalizma rasprostranjen je u srednjoj Europi, a dobar primjer, osim Habsburške Monarhije, pruža i njemački prostor. Postoji niz usporednica u razvoju modernog građanstva i tijeka modernizacije u Njemačkoj i Hrvatskoj, dakako, s vremenskim odmakom koji je posljedica hrvatske slabije razvijenosti. Naime, potpuno nepostojanje samostalne države te posvemašnja nerazvijenost obilježava Hrvatsku, a kasno osnivanje moderne države i kašnjenje u razvoju kao europske i kolonijalne sile obilježava Njemačku. To je etiologija potrebe za čvrstom središnjom vlasti koja će brzo i efikasno provesti reforme relevantne za cijelo društvo i državu, a ne za status i slobodu pojedinca.

Mažuranićeva želja da se napokon u Hrvatskoj počne s temeljitim modernizacijskim reformama jasno je izrečena u njegovu govoru prilikom izbora za predsjednika Hrvatskoga sabora 19. siječnja 1872. Rekao je tada Mažuranić: „Gospodo moja! Vi ste izabrani pod zastavom reformah. Reformah treba našoj zemlji u svakoj struci, u struci pravosudja, u struci uprave, u struci školstva. (...). Vi ćete gledati, da ako i ne postignete kulminaciju tih strukah u drugih zemljah, da ih barem pribiližite onomu stepenu na kojem se nalaze u inih civiliziranih zemljah. ${ }^{\text {29 }} \mathrm{U}$ tim riječima naziremo napor da Hrvatska nadoknadi zaostatak za razvijenim zapadnoeuropskim zemljama, cilj kojem i danas stremimo. Također razvidnim postaje i Mažuranićevo značenje kao intelektualca nacionalnog profila, ali i europskih dometa. On je orijentiran na napredak vlastite zemlje i nije intelektualac poput Baltazara Bogišića, koji se izdignuo iznad nacionalnih okvira, ali također ni tip intelektualca isključivo uronjenog u vlastito nacionalno biće. ${ }^{30}$ Napredak vlastite zemlje i nacije za Mažuranića nije podrazumijevao gubitak europske dimenzije, a još manje nacionalnu isključivost. ${ }^{31}$

U vrlo kratkom vremenu od 1873. do 1875. u Hrvatskom su saboru odobrena čak 32 zakonska prijedloga, što je izuzetno velik reformni napor i prema suvremenim kriterijima, a nekmoli onima 19. stoljeća. Većinu zakonskih prijedloga formulirala je hrvatska Vlada, koja se time pokazala kao izuzetno aktivna, kao

28 Iako je usvajanjem zakona o emancipaciji Židova Sabor pozvao Vladu da to učini za sve konfesije, ona to nije provela. Vjerojatno je posrijedi bilo pitanje organizacije protestantske crkve u Hrvatskoj. Dok se s hrvatske strane željelo ustrojiti autonomnu hrvatsku crkvu, s mađarske se preferirala zavisnost o ugarskoj crkvi. KROKAR 1980: 219-220.

29 MAŽURANIĆ 1979: 215.

30 JANKOVIĆ 2012: 57-80.

31 Uostalom, supruga mu je pravoslavka grčkog podrijetla, Aleksandra Demeter, sestra Dimitrijeva. Prema zapisu njihove unuke I. Brlić Mažuranić, Aleksandra je bila sušta suprotnost svome racionalnom, trezvenom i odmjerenom suprugu. BRLIĆ-MAŽURANIĆ 1997: 523. 
inicijator zakona. Mažuranić je tako nastojao čvrsto držati konce u rukama, odlučan u namjeri provođenja programa. Taj je načelni čovjek bio istodobno politički realist, spreman na stanovite kompromise ako su oni značili put do krajnjeg cilja. Jasno je to demonstrirao prilikom mađarskog neprihvaćanja prijedloga zakona o odgovornosti bana i triju odjelnih predstojnika te odbijanja ukidanja časti velikih župana, kao i otpora Crkve, ali i srpskih političara 32 školskom zakonu. Premda je Mažuranić želio da Zemaljska vlada postane prava parlamentarna odgovorna vlada, morao je pod mađarskim pritiskom odustati od odgovornosti odjelnih predstojnika svoje Vlade, postulirajući samo odgovornost bana kao njena čelnika. Međutim, u sljedećem se okršaju s Budimpeštom Mažuranić pokazao vještim političkim igračem. Naime, iz Budimpešte je jasno poručeno da ukidanje dužnosti i časti velikih župana, predloženo u nacrtu zakona o ustroju političke uprave, ne dolazi u obzir. Bitni razlozi za takav stav bili su činjenica da je velike župane imenovao vladar slijedeći sugestije mađarske Vlade, koja je tako mogla direktno utjecati na unutarnju političku situaciju u Banskoj Hrvatskoj, te neriješeno pitanje reforme uprave u Ugarskoj, u kojoj su tada bili suprotstavljeni stavovi centralista i municipalista. ${ }^{33}$ No, valja istaknuti kako su Mađari imali nedvojbeno jak argument. Budući da su veliki župani ujedno i virilisti ne samo Hrvatskog nego i Ugarskog sabora, nije ih moguće unilateralno ukinuti, tj. za takav je potez nužna odluka i Ugarskoga sabora. Mažuranić je, međutim, našao način kako da udovolji tom formalno opravdanom zahtjevu, ali i ostvari svoju nakanu modernizacije uprave. Stoga je legislativa o županijama zapravo velik dio tekućih poslova prenijela na podžupane. Primjer je nužnog kompromisa i zakon o pučkom školstvu i učiteljskim preparandijama, kojim se Mažuranić potrudio provesti veliki iskorak u modernizaciji i laicizaciji školstva, osiguravši pritom da ne dođe do otvorenog sraza između svjetovne i crkvene vlasti, što bi uvelike uzdrmalo poziciju njegove Vlade. Naime, i perjanice hrvatskog liberalnog katolicizma poput Strossmayera i Račkoga oštro su osuđivali čak i tako umjeren prijedlog zakona. ${ }^{34}$ Stoga se, prije nego što je prijedlog zakona došao u Sabor, potrudio donekle ublažiti otpor svećenstva, a sam je zakonski prijedlog bio bitno umjereniji negoli austrijski predložak po kojem je rađen. ${ }^{35}$ Crkva je i dalje imala stanovit utjecaj u školstvu, a svećenici su bili članovi školskih odbora.

\footnotetext{
32 GROSS 1988: 75-117.

33 GROSS I SZABO 1992: 379-380.

34 Također im je trn u oku bio Friedrich Dittes, ravnatelj bečkog Paedagogiuma i uzor hrvatskih liberalnih učitelja. Vidi npr. pisma: Rački Strossmayeru (17. travnja 1872., 11. travnja i 28. kolovoza 1874.), Strossmayer Račkom (17. ožujka i 15. kolovoza 1874.), ŠIŠIĆ 1928.

35 O austrijskom školskom zakonu (Reichsvolksschulgesetz) iz 1869. vidi ENGELBRECHT 1984: 117.
} 
Kao ban, Mažuranić je bio čelnikom najbolje hrvatske Vlade u razdoblju do 1918. godine. Njegov politički diskurs bio je sažet i precizan, ali istodobno obilježen sentencioznošću koja krasi njegov književni stil. Svoj moto „Neka se misli krešu“ primjenjivao je u politici. Poštovao je i slušao tuđa mišljenja u potrazi za najboljim idejama i praktičnim rješenjima, ali je pritom dosta čvrsto držao konce u svojim rukama. Suzdržani i praktični Mažuranić predstavljao je suprotnost vehementnom Anti Starčeviću. No, Hrvatskoj su bila potrebna oba tipa političara: i samozatajni realni političar i britki ideolog. Uostalom, kako je vispreno zaključio Antun Barac, „Za konačne i velike svrhe mogu živjeti i raditi, pa i žrtvovati se, samo pojedinci. Narod pak kao cjelina mora živjeti i u vremenima, kad su velike misli daleko od ostvarenja. [...] Ljudi, koji su spremni raditi za narod i u takvim vremenima [...] nikad ne mogu za sobom povući većih masa, jer sve svoje snage moraju često trošiti na rješavanje sitnica, od kojih se ipak sastoji život.“36

U svjetlu rečenoga, primjereno je da je Mažuranić odustao od tradicionalnih raskošnih banskih instalacija koje su davale dojam da je ban moćan dužnosnik. „Ban pučanin“ opravdao je taj naziv čak i na simboličkoj razini. Za razliku od Levina Raucha, koji je 1869. za sebe dao prirediti vrlo raskošnu svečanost banskog ustoličenja po tradicionalnom ceremonijalu ${ }^{37}$, skromni i građanski orijentirani Mažuranić bio je zadovoljan svečanim dočekom na zagrebačkom kolodvoru. Tako je i na razini simbola i ceremonija Mažuranić označio pomak prema modernoj građanskoj kulturi. Uostalom, sam je Mažuranić na samom početku svoga banovanja, najavljujući prijedlog zakona o odgovornosti bana i odjelnih predstojnika, vrlo jasno rekao kako ban više nije ,feudalni dostojanstvenik, nego po slovu ovoga zakona vršitelj složne volje Njegova Veličanstva i ovoga naroda.“"38

Započela sam tekst navođenjem slike iz Mažuranićeva privatna života, pa bih tako i završila. I u krugu svojih najbližih Mažuranić je i nehotice djelovao autoritativno, kao mudri stari patrijarh. Takvim ga je doživjela njegova čuvena unuka Ivana Brlić-Mažuranić prilikom svakodnevnih večernjih susreta proširene obitelji u kući u Jurjevskoj ulici. Ivana Brlić Mažuranić u svojoj je autobiografiji zapisala: „Stolu je predsjedavao djed sam, razgovore je rukovodio on, a njegova

36 BARAC 1945: 41.

37 Svečanosti su trajale 3 dana i imale su svoj pučki i elitni dio. Pučka veselica priređena je 9. rujna na Zrinjevcu, a narod je počašćen pečenim volom, s 50 vedara vina i 2000 komada kruha, uz glazbu i pucanje mužara. Veselica je trajala do 3 ujutro, a okićena volova glava svečano je uručena banu. Eliti je sljedećega dana bio namijenjen svečani ples u nadbiskupskom dvoru. Pozvano je oko 1000 pripadnika odabrane elite, a slavlje je potrajalo do 1 sat ujutro. Da gostima ne ponestane okrepe pobrinuo se slastičar Franjo Krežma, isporučivši 1000 porcija sladoleda i holipa, 2400 slastica, 100 soka limunade i narančade, 200 čaša kave, 115 funta slastica, šećera, čokolade i suhoga voća, 600 šalica čaja te 1000 komada čajnoga peciva! IVELJIĆ 2014: 148150 .

38 Govor u Hrvatskom saboru od 12. siječnja 1874. u: MAŽURANIĆ 1979: 321. 
tjelesno i duševno tako moćna pojava vršila je nedokučiv upliv na moje biće [...]. Svaka njegova riječ, svaka rasprava (u rasprave se rado upuštao i nije dao da predmet padne dok ne bi iscrpljen bio) bila je uzvišena umom, a još uzvišenija u onoj čistoći i strogosti etičkih nazora kojom kano da je taj silni starac prožimao svu okolinu svoju, sav dom svoj, sve koljeno svoje.“" ${ }^{\text {39 }}$

\section{Bibliografija}

BARAC, Antun. 1945. Mažuranić. Zagreb: Matica hrvatska.

BRANDT, Harm-Hinrich Brandt. 1988. Liberalismus in Österreich zwischen Revolution und großer Depression. U LANGEWIESCHE 1988: 136-160.

BRLIĆ-MAŽURANIĆ, Ivana. 1997. Autobiografija. U Vinko Brešić, Autobiografije hrvatskih pisaca. Zagreb: AGM.

COHEN, Gary B. 2007. Nationalist Politics and the Dynamics of State and Civil Society in the Habsburg Monarchy 1867-1914. Central European History 40: 241-278.

CORNWALL, Mark. 2010. The Habsburg Elite and the Southern Slav Question 19141918. U A Living Anachronism? European Diplomacy and the Habsburg Monarchy. Festschrift für Francis Roy Bridge zum 70. Geburtstag, ur. Lothar Höbelt i T. G. Otte, 239-270. Beč, Köln, Weimar: Böhlau Verlag.

ČEPULO, Dalibor. 1998. Ustavne i političko-upravne zakonodavne reforme u Hrvatskoj u razdoblju banovanja Ivana Mažuranića: ustrojstvo vlasti i građanske slobode i prava. Doktorski rad, Pravni fakultet Sveučilišta u Zagrebu.

ČEPULO, Dalibor. 1999. Pravo na javno okupljanje u Hrvatskoj 1848.-1918. i odrednice razvoja u europskim zakonodavstvima. Zbornik Pravnog fakulteta u Zagrebu 49/3-4: 397-427.

ČEPULO, Dalibor. 2000. Središte i periferija: europske i hrvatske odrednice Mažuranićevih reformi ustrojstva vlasti i građanskih prava (1873-1880). Zbornik Pravnog fakulteta u Zagrebu 50/6: 889-920.

DIPPER, Christof. 1988. Adelsliberalismus in Deutschland. U LANGEWIESCHE 1988: 172-192.

ENGELBRECHT, Helmut. 1984. Geschichte des österreichischen Bildungswesens. Erziehung und Unterricht auf dem Boden Österreichs. Sv. 4: Von 1848 bis zum Ende der Monarchie. Beč: ÖBV.

FOUCAULT, Michel. 1990. Predavanja. Novi Sad: Bratstvo - jedinstvo.

GROSS, Mirjana. 1960. Vladavina Hrvatsko-srpske koalicije 1906-1907. Beograd: Institut društvenih nauka.

GROSS, Mirjana. 1985. Počeci moderne Hrvatske. Neoapsolutizam u civilnoj Hrvatskoj i Slavoniji 1850-1860. Zagreb: Delo, Globus, Centar za povijesne znanosti Sveučilišta u Zagrebu.

39 BRLIĆ-MAŽURANIĆ 1997: 522. 
GROSS, Mirjana. 1988. Zakon o osnovnim školama 1874. i sprsko pravoslavno školstvo. Zbornik radova o povijesti i kulturi srpskog naroda u Socijalističkoj Republici Hrvatskoj, knj. 1, ur. Dušan Čalić, 75-117. Zagreb: JAZU.

GROSS, Mirjana. 2000. Izvorno pravaštvo. Ideologija, agitacija, pokret. Zagreb: Golden marketing, Tehnička knjiga.

GROSS, Mirjana. 2004. Vijek i djelovanje Franje Račkoga. Zagreb: Novi liber.

GROSS, Mirjana, Agneza SZABO. 1992. Prema hrvatskome građanskom društvu. Zagreb: Globus.

IVELJIĆ, Iskra. 2009. Modernisierung Kroatiens in der zweiten Hälfte des 19. Jahrhunderts. Europäische Vorbilder und kroatische Besonderheiten“. U Vorbild ,Europa “ und die Modernisierung im 19. und 20. Jahrhundert, ur. Flavius Solomon, Krista Zach, Juliane Brandt, 25-45. Berlin: Lit Verlag.

IVELJIĆ, Iskra. 2011. Prosvjeta Banske Hrvatske u 19. stoljeću. U Zbornik Nikše Stančića, ur. Iskra Iveljić, 125-138. Zagreb: Filozofski fakultet Sveučilišta u Zagrebu, Odsjek za povijest, FF-press.

IVELJIĆ, Iskra. 2014. Anatomija jedne velikaške porodice. Rauchovi. Zagreb, FF-press.

JANKOVIĆ, Branimir. 2012. Odnos prestižnih profesija i društva u 19. stoljeću na primjeru Franje Račkog, Stojana Novakovića i Baltazara Bogišića. U Baltazar Bogišić $i$ njegovo doba u intelektualnohistorijskoj perspektivi, ur. Drago Roksandić, Branimir Janković, 57-80. Zagreb: FF press.

KASCHUBA, Wolfgang. 1988. Zwischen Deutscher Nation und Deutscher Provinz. Politische Horizonte und soziale Milieus im frühen Liberalismus. U LANGEWIESCHE 1988: 83-108.

KONTLER, László. 2007. Povijest Mađarske. Tisuću godina u Srednjoj Europi. Zagreb: Srednja Europa.

KROKAR, James. 1980. Liberal Reform in Croatia, 1872-75: The Beginnings of modern Croatia under Ban Ivan Mažuranić. Phil. Diss., Indiana University.

KRTALIĆ, Ivan. 1986. Iso Kršnjavi ili pozicija subjekta u centru. U Zapisci. Iza kulisa hrvatske politike, sv. 1, ur. Ivan Krtalić, V-XII. Zagreb: Mladost.

LANGEWIESCHE, Dieter (ur.). 1988. Liberalismus im 19. Jahrhundert. Deutschland im europäischen Vergleich. Göttingen: Vandenhoeck \& Ruprecht.

MAŽURANIĆ, Ivan. 1979. Sabrana djela. Sv. IV: Pisma. Govori. Priredio Milorad Živančević. Zagreb: Svečilišna naklada Liber, Nakladni zavod Matice hrvatske.

MILLER, Nick. 1997. Between Nation and State. Serbian Politics in Croatia Before the First World War. Pittsburgh: Universty of Pittsburgh Press.

PAVIĆ, Armin. 1875. O kompoziciji Gundulićeva Osmana. Rad JAZU 32: 104-150.

PERŠIĆ, Ivan. 2002. Kroničarski spisi. Priredio Stjepan Matković. Zagreb: Državni arhiv u Zagrebu, Dom i svijet, Hrvatski institut za povijest.

Sbornik zakona za 1874. Zagreb 1876.

SCHÖDL, Günter. 1990. Kroatische Nationalpolitik und „Jugoslavenstvo“. München: Oldenbourg Verlag. 
ŠENOA, August. 1951. Moji zapisi. Počam od 1880. godine. U ISTI, Djela, sv. I. Zagreb: Zora, 577-588.

ŠIŠIĆ, Ferdo (ur.). 1928. Korespondencija Rački-Strossmayer. Sv. 1. Zagreb: JAZU.

Zakoni o ugarsko-hrvatskoj nagodbi. 1907. Prir. Ivan pl. Bojničić. Zagreb: Naklada knjižare Mirka Breyera.

ŽUPAN, Dinko. 2002. Pučko školstvo u vrijeme banovanja Ivana Mažuranića. Magistarski rad, Filozofski fakultet Sveučilišta u Zagrebu.

\section{Controlled Modernization under Ban Ivan Mažuranić}

The author discusses the attitudes of Croatian intelligentsia towards political authority during the Dualist period of the Habsburg Monarchy and analyses the liberal reforms of ban Ivan Mažuranić, as a type of controlled modernization.

Keywords: Ivan Mažuranić, modernization, politics, nation, intellectual elite.

Ključne riječi: Ivan Mažuranić, modernizacija, politika, nacija, intelektualna elita.

Iskra Iveljić

Filozofski fakultet Sveučilišta u Zagrebu Ivana Lučića 3 HR-10000 Zagreb iiveljic@ffzg.hr 


\section{FILOZOFSKI FAKULTET SVEUČILIŠTA U ZAGREBU \\ ZAVOD ZA HRVATSKU POVIJEST \\ INSTITUTE OF CROATIAN HISTORY \\ INSTITUT FÜR KROATISCHE GESCHICHTE}

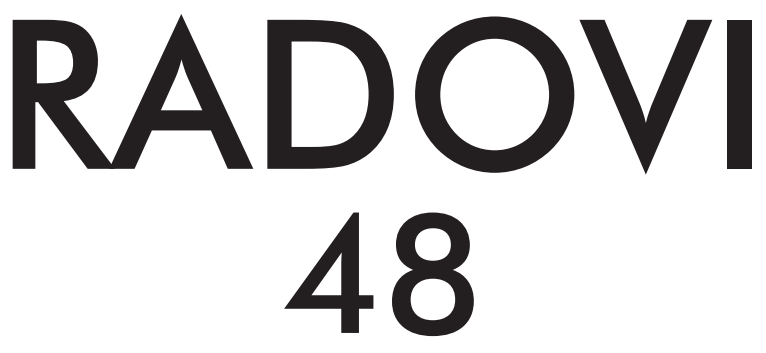

ZAVOD ZA HRVATSKU POVIJEST

FILOZOFSKOGA FAKULTETA SVEUČILIŠTA U ZAGREBU

\section{FF press}

ZAGREB 2016. 


\title{
RADOVI ZAVODA ZA HRVATSKU POVIJEST FILOZOFSKOGA FAKULTETA SVEUČILIŠTA U ZAGREBU \\ Knjiga 48
}

\author{
Izdavač / Publisher \\ Zavod za hrvatsku povijest \\ Filozofskoga fakulteta Sveučilišta u Zagrebu \\ FF-press \\ Za izdavača / For Publisher \\ Željko Holjevac \\ Glavni urednik / Editor-in-Chief \\ Hrvoje Gračanin \\ Izvršna urednica / Executive Editor \\ Inga Vilogorac Brčić \\ Uredništvo / Editorial Board
}

Bruna Kuntić-Makvić (stara povijest/ancient history), Zrinka Nikolić Jakus (srednji vijek/ medieval history), Hrvoje Petrić (rani novi vijek/early modern history), Željko Holjevac (moderna povijest/modern history), Tvrtko Jakovina (suvremena povijest/contemporary history),

Silvija Pisk (mikrohistorija i zavičajna povijest/microhistory and local history),

Zrinka Blažević (teorija i metodologija povijesti/theory and methodology of history)

Međunarodno uredničko vijeće / International Editorial Council

Denis Alimov (Sankt Peterburg), Živko Andrijašević (Nikšić), Csaba Békés (Budapest), Rajko Bratož (Ljubljana), Snježana Buzov (Columbus, Ohio), Svetlozar Eldarov (Sofija), Toni Filiposki (Skopje), Aleksandar Fotić (Beograd), Vladan Gavrilović (Novi Sad), Alojz Ivanišević (Wien),

Egidio Ivetić (Padova), Husnija Kamberović (Sarajevo), Karl Kaser (Graz),

Irina Ognyanova (Sofija), Géza Pálffy (Budapest), Ioan-Aurel Pop (Cluj),

Nade Proeva (Skopje), Alexios Savvides (Kalamata), Vlada Stanković (Beograd), Ludwig Steindorff (Kiel), Peter Štih (Ljubljana)

\section{Izvršna urednica za tuzemnu i inozemnu razmjenu / Executive Editor for Publications Exchange \\ Kristina Milković}

Tajnik uredništva / Editorial Board Assistant
Dejan Zadro

Adresa uredništva/Editorial Board address

Zavod za hrvatsku povijest, Filozofski fakultet Zagreb, Ivana Lučića 3, HR-10 000, Zagreb

Tel. ++385 (0)1 6120 150, 6120 158, faks ++385 (0)1 6156879

Časopis izlazi jedanput godišnje / The Journal is published once a year

Časopis je u digitalnom obliku dostupan na / The Journal in digital form is accessible at Portal znanstvenih časopisa Republike Hrvatske „Hrčak“ http://hrcak.srce.hr/radovi-zhp

Financijska potpora za tisak časopisa / The Journal is published with the support by

Ministarstvo znanosti, obrazovanja i športa Republike Hrvatske

Časopis je indeksiran u sljedećim bazama / The Journal is indexed in the following databases:

Directory of Open Access Journals, EBSCO, SCOPUS, ERIH PLUS, Emerging Sources Citation Index - Web of Science 


\section{Naslovna stranica}

Iva Mandić

Grafičko oblikovanje i računalni slog

Marko Maraković

\section{Lektura}

Samanta Paronić (hrvatski / Croatian)

Dražen Nemet (engleski / English)

Tisak

Tiskara Zelina d.d., Sveti Ivan Zelina

Naklada

250 primjeraka

Časopis je u digitalnom obliku dostupan na Portalu znanstvenih časopisa Republike Hrvatske ,Hrčak" http://hrcak.srce.hr/radovi-zhp

The Journal is accessible in digital form at the Hrcak - Portal of scientific journals of Croatia http://hrcak.srce.hr/radovi-zhp 


\section{RADOVI 48}

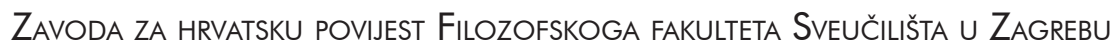

